\title{
Chromosome Numbers of Hawaiian Angiosperms: New Records and Comments ${ }^{1}$
}

\author{
Michael Kiebn ${ }^{2}$
}

\begin{abstract}
In this paper chromosome counts for 90 collections representing 67 native Hawaiian angiosperm species and eight hybrids in 22 families are presented and discussed. Included are the first records for 26 species, two subspecific taxa, eight natural hybrids, and the endemic genus Pteralyxia (Apocynaceae). In four families Hawaiian representatives have been investigated cytologically for the first time. For three species the investigations are the first on Hawaiian material. Seven counts differ from earlier reports in the literature. Implications of the results are discussed in the context of autochthonous chromosomal evolution and of colonization events for the Hawaiian Islands.
\end{abstract}

Chromosome numbers are available for nearly $40 \%$ of the native Hawaiian species (Carr 1998). In most cases these numbers were obtained from counts of single or very few individuals. In this paper it is aimed to improve the knowledge on chromosome numbers for Hawaiian angiosperms, both with regard to taxa not previously investigated and for additional collections of taxa already counted. Data for 19 species presented here were shared with G. Carr (University of Hawai'i at Mānoa, Honolulu) and were included in his earlier survey (Carr 1998, table 1.1) as "Kiehn unpubl." These counts are documented and discussed further here and are footnoted "c" in Table 1.

\section{MATERIALS AND METHODS}

In the course of eight visits to Hawai' $i$ between 1989 and 2003, fixations of actively

\footnotetext{
${ }^{1}$ Parts of this study were supported financially by the Austrian Science Foundation (FWF-proj. P-13107-Bio), the Österr. Forschungsgemeinschaft (proj. 06/3699), the Hochschuljubiläumsstiftung der Stadt Wien (proj. $\mathrm{Nr}$. H-21/94), and the National Tropical Botanical Garden, Lāwa'i, Kaua'i, Hawai'i. Manuscript accepted 20 August 2004.

2 Institute of Botany, University of Vienna, Rennweg 14, A-1030 Vienna, Austria (e-mail: michael.kiehn@ univie.ac.at).
}

Pacific Science (2005), vol. 59, no. 3:363-377

(C) 2005 by University of Hawai'i Press

All rights reserved growing root tips, shoot apices, or young flowers for mitotic counts, or young flower buds for meiotic investigations of plants cultivated at the National Tropical Botanical Garden, Lāwa'i, Kaua'i, Hawai'i (NTBG), and of plants collected in the wild were made in a freshly mixed $3: 1$ solution of ethanol (96\%): glacial acetic acid. In each field fixation, only one individual was sampled (except for Labordia degeneri, DL6453, collected and fixed by D. Lorence, where several individuals may have been sampled in the same fixation). Additional fixations of root tips were taken from plants cultivated at the Botanical Garden of the University of Vienna, Austria (HBV), from seeds collected in Hawai'i; the root tips were pretreated in 8-hydroxyquinoline $\left(0.002 \mathrm{~m}\right.$, ca. $6 \mathrm{hr}$ at $\left.8-10^{\circ} \mathrm{C}\right)$. Each root tip fixation represented one individual. The fixed material was stored at $8-10^{\circ} \mathrm{C}$ before staining with Giemsa (after hydrolysis in $5 \mathrm{~N}$ $\mathrm{HCl}$ for $50 \mathrm{~min}$. at $20^{\circ} \mathrm{C}$ ) or with Feulgen (Kiehn 1995). Hot aceto-carmine (2\% solution in $45 \%$ acetic acid) was used to intensify staining if needed. Somatic chromosome numbers $(2 n)$ were established from any of several tissue sources, including premeiotic anthers, young flower buds, young ovaries, ovary wall, and root tips. Gametic number determinations $(n)$ were derived from meiotic divisions of microsporocytes. Collection data for each studied sample are listed in Table 1. Voucher specimens have been deposited in the herbaria at the University of Vienna (wu), at the National Tropical Botanical Gar- 
den (РтвG), and/or in other herbaria as stated in Table 1. Permanent slides for most of the counts are in the collection of the author.

\section{RESULTS}

Chromosome counts for 67 species (90 collections) of native Hawaiian angiosperms from 22 families are presented in Table 1. They include the first chromosome number reports for 26 species, two subspecific taxa, eight natural hybrids, and the endemic genus Pteralyxia (Apocynaceae). In four families (Droseraceae, Myrsinaceae, Orchidaceae, and Viscaceae) Hawaiian representatives have been investigated cytologically for the first time. For three indigenous Hawaiian species the investigations are the first ones on Hawaiian material. Counts for seven species differ from earlier reports; 18 counts are in accordance with earlier published data. Some chromosome numbers are reported as a range. This is the case in taxa with high chromosome numbers (e.g., in Hedyotis spp. or Coprosma ernodeoides) where different counts on several individuals led to differing results, or was caused by chromosomes sticking together during fixation (e.g., in Alyxia, Labordia, Liparis, or Korthalsella).

\section{DISCUSSION}

Discussion of the new data in a taxonomic context

APOCYNACEAE: The results reported here for Alyxia stellata (=A. oliviformis, cf. Middleton 2000) and for Pteralyxia kauaiensis (first count for the genus) are in line with previous reports for the genus Alyxia (Skottsberg 1955: $2 n=$ ca. $36,2 n=$ ca. 39 for $A$. stellata; Van der Laan and Arends 1985: $2 n=36$ for two non-Hawaiian Alyxia species). The reported range of $2 n=34-36$ is caused by the relatively large chromosomes being twisted around each other in the available fixations.

araliaceae: According to molecular data, the Hawaiian genera Munroidendron, Reynoldsia, and Tetraplasandra are closely related to each other (Wen et al. 2001). The monotypic Munroidendron and one species of Tetraplasan- dra have been counted so far; both are tetraploids with $n=24 / 2 n=48$ (Carr 1978, 1998, Kiehn and Lorence 1996). The data reported here for Tetraplasandra bisattenuata $(2 n=46-$ 48) fit well into the picture for this group.

CaMPanulaceaE: The chromosome number determinations for seven species, five of which are new counts, are in accordance with the earlier data for Hawaiian species summarized by Lammers (1988) and Carr (1998). All Hawaiian taxa of the family cytologically investigated to date exhibit $2 n=28$; Carr (1998) considered single deviating reports to be erroneous, a view corroborated by the results presented here.

CARYophyllaceae: Of the seven Hawaiian species of Silene, S. alexanderi from Moloka'i reported here is the third to be counted (see Carr 1998). All three species exhibit $2 n=24$, in agreement with $x=12$ as the predominant basic number for Silene (cf., e.g., Goldblatt and Johnson 2000).

CYPERACEAE: The chromosome number for Eleocharis obtusa is established for the first time on Hawaiian material. The result of $2 n=10$ is in accordance with earlier counts for this species (e.g., from northeastern America [Gervais and Cayouette 1985]).

Droseraceae: The first count for Drosera anglica on material from Hawai'i revealed $2 n=40$. This result is in accordance with earlier reports for this, by Murín and Májovský (1987) from Europe and by Kondo and Segawa (1988) from Asia. Thus there is no apparent variation in the chromosome number of this species across its whole range of distribution. In contrast, the genus Drosera in general is extremely variable in basic numbers (ranging from $x=3$ to $x=9$, with additional reports of $x=13$ and $x=15$ [Kondo and Lavarack 1984, Kondo and Segawa 1988, Sheikh and Kondo 1995]) and in ploidy levels (from diploidy to dodecaploidy [Kondo and Lavarack 1984, Sheikh and Kondo 1995]).

ERICACEAE: Two of the three native Hawaiian Vaccinium species ( $V$. calycinum, $V$. reticulatum) have already been counted; both exhibit $2 n=24$ (Carr 1998). The result of $2 n=48$ obtained here for Vaccinium cf. dentatum from Moloka'i indicates the presence 
of tetraploidy in Hawaiian representatives of the genus.

The three native Hawaiian Vaccinium species, together with the southern Polynesian species $V$. cereum, form the monophyletic sect. Macropelma of Vaccinium (Vander Kloet 1996). Vander Kloet (1996) hypothesized that the Hawaiian taxa compose a coherent evolutionary unit of occasionally anastomosing selfing lineages. The production of such hybrid lineages could explain the presence of two ploidy levels among the Hawaiian taxa. The difficulties in identifying the investigated Vaccinium collection from Moloka'i could also be due to a hybrid origin of the investigated collection. It would be desirable to study meiotic divisions in this group or to use molecular fingerprint methods to further evaluate the hypothesis of Vander Kloet (1996).

geraniaceae: The genus Geranium is represented in Hawaici by six native species. The chromosome number established here for Geranium cuneatum subsp. tridens from East Maui $(2 n=48-52)$ is in the same range as the only earlier report available for a Hawaiian species (G. arboreum: $2 n=\mathrm{ca} .50$ [Carr 1978, 1998]) and similar to four reports for New Zealand species ranging from $2 n=52$ to $2 n=56$ (Dawson and Beuzenberg 2000). A survey of chromosome counts for Geranium (http://www.rjb.csic.es/Geranium/ index_geranium.html) reports basic numbers for the genus as $x=n=9,10,11,12$, $13,14,15,16,17,21$ ? $, 23,25$, with a predominance of $x=14$. Although chromosome morphology and numbers proved very useful for the systematic treatment of the related genus Pelargonium (Gibby et al. 1996), there are no published studies relating the chromosome data of Geranium to a comprehensive taxonomic treatment of the genus.

GESNERIACEAE: Counts are now available for 24 of the 58 Hawaiian species of Cyrtan$d r a$ and for eight naturally occurring hybrids (Table 1 and Storey 1966). The counts cover all sections of the genus in Hawai'i as recognized by Wagner et al. (1999).

All collections that allowed an exact count revealed a chromosome number of $n=17$ or $2 n=34$, as did all other Cyrtandra species counted so far (with the exception of three reports by Borgmann 1964 for taxa from New Guinea [see Kiehn and Weber 1998 for discussion]). The genus proves to be very uniform karyologically. Some variation in chromosome length and size (as discussed by Storey 1966) can be seen in Hawaiian material, but this is (at least partly) caused by differences in fixation and pretreatments, because such variation was also observed in different fixations of the same taxon (e.g., of $C$. bawaiensis and of $C$. paludosa).

Ranges of numbers given for $C$. grayi, $C$. kalibii, C. lessoniana, and C. platyphylla are due to the poor quality of the respective fixations and most probably do not reflect a real range of chromosome numbers in these species. In the case of the C. lessoniana collection, this assumption is supported by the observation of regular meiotic divisions. Regular meiotic divisions are also present in collections of C. hawaiensis, C. kauaiensis, C. paludosa var. paludosa, C. sandwicensis, and in two putative hybrids. However, meiotic irregularities were found in the investigated material of $C$. grandiflora and C. munroi. In spite of cytoplasmic bridges and the presence of abnormal pollen grains, $C$. grandiflora clearly revealed $n=17$ in regular divisions. However, the range given for $C$. munroi could reflect true variation. Collection $M K-990913-3 / 2$ of this species exhibited meiotic irregularities, including anaphase bridges, lagging univalents, cytoplasmic bridges between pollen mother cells (PMCs), and a high frequency of abnormal pollen.

All investigated (putative) hybrids and their (hypothetical) parents are on the same ploidy level and have the same chromosome numbers. Only one of the eight hybrids analyzed showed meiotic irregularities (hybrid II from Maui had degenerated pollen). Pollen viability tested by Luegmayr (1993) for 16 accessions of 12 different interspecific hybrids of Hawaiian Cyrtandra was between 70 and $99 \%$ for 15 of those accessions. Only one accession showed a very low viability (of $2 \%$ ). Germination rates of seeds from six interspecific hybrids were all approximately $90 \%$, similar to those of true species (unpubl. data). Thus, it can be assumed that most natural hybrids between Hawaiian Cyrtandra species are 


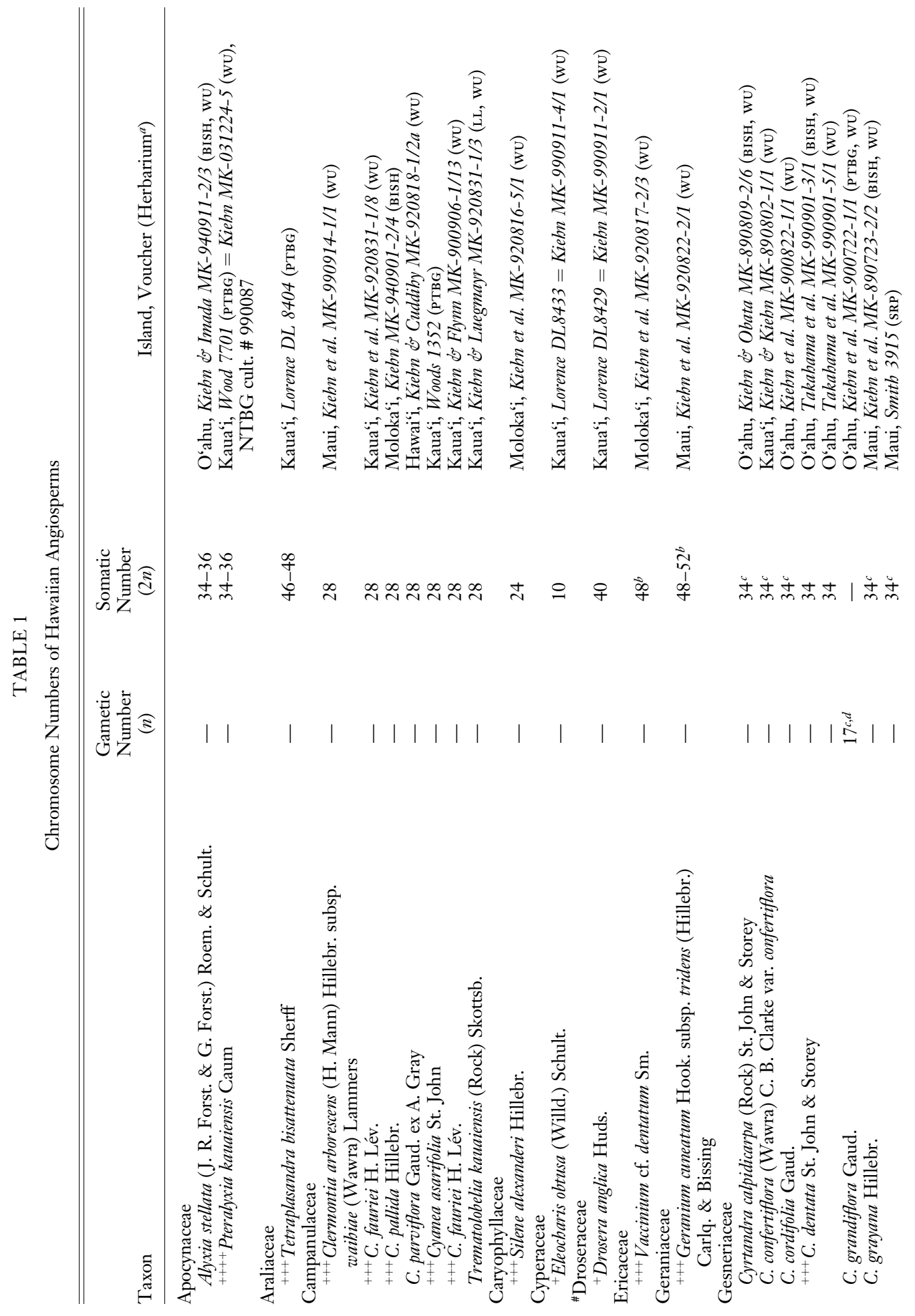




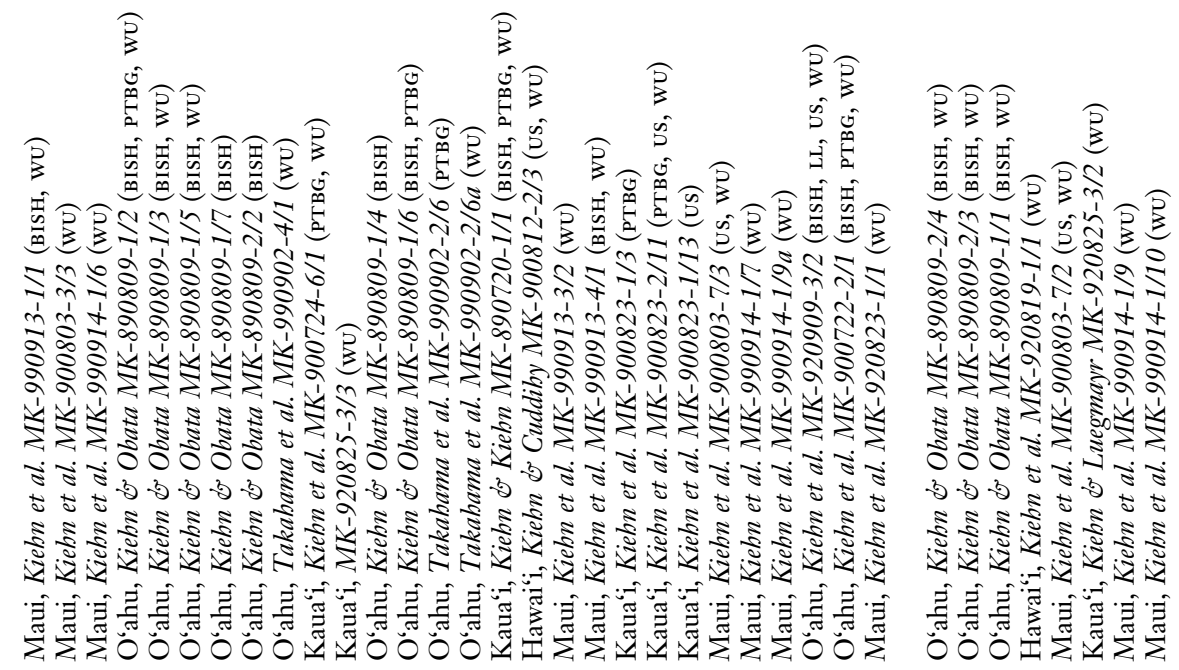

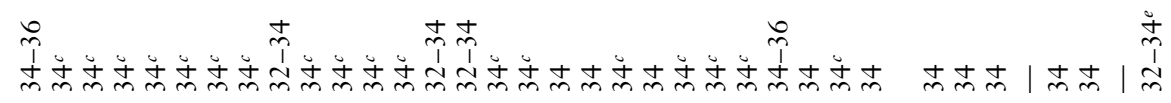

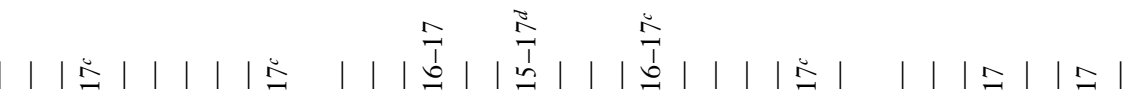

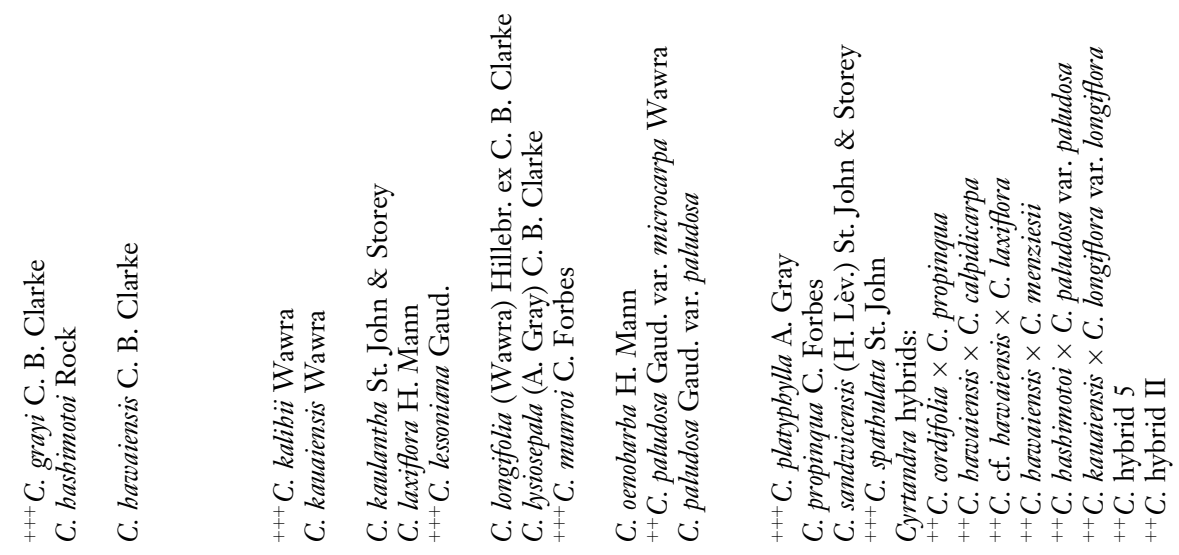




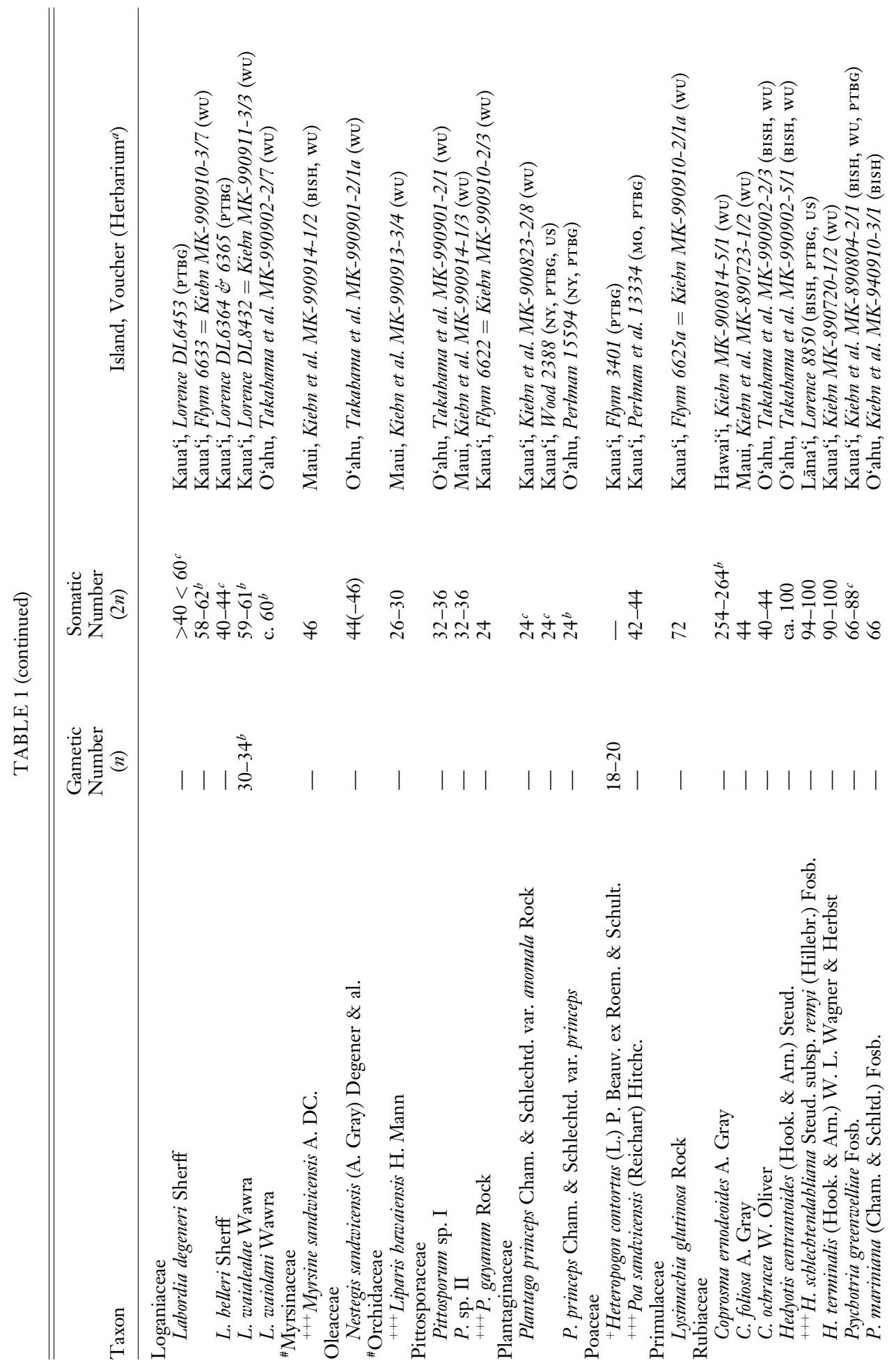




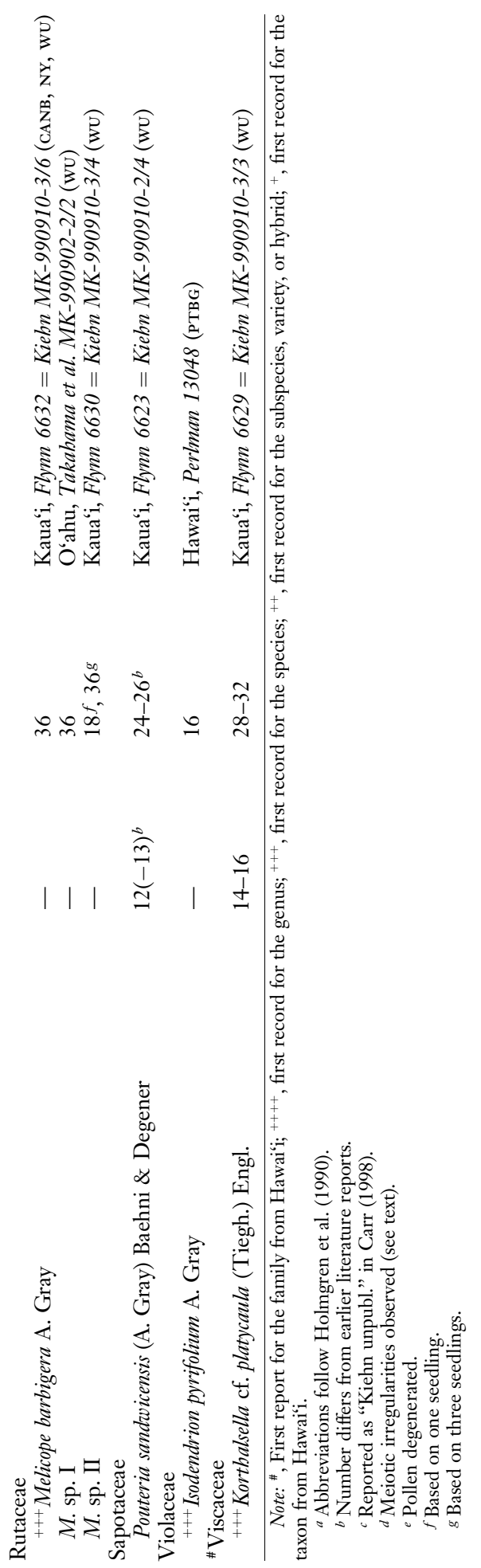


fully fertile. Of particular interest in this regard is Smith 2874, a collection of Cyrtandra from $\mathrm{O}^{\prime}$ ahu that has been independently identified as an $\mathrm{F}_{1}$ hybrid between C. cordifolia and C. laxiflora by W. L. Wagner (Smithsonian Institution) and myself. A seedling from a fruit of this hybrid regularly sets flowers at the Botanical Garden, University of Vienna. Morphologically, this plant cannot be distinguished from one of the parents of the $\mathrm{F}_{1}$ hybrid, C. laxiflora. More work on hybrids (in particular with larger numbers of plants) is desirable to further interpret this observation. One explanation could be that species differences are based on only a few genes, and backcrosses of an $F_{1}$ hybrid with one of the parental species yield progeny very similar to the recurrent parental species. This would explain the observation of individual $F_{1}$ hybrid plants between sympatrically growing Cyrtandra species and the apparent lack of "hybrid swarms" in Cyrtandra in Hawai'i. Carr (1995) discussed the potential relevance of hybridization to plant evolution in the Hawaiian Islands based on an example in the AsteraceaeMadiinae.

Loganiaceae (geniostomaceae): Recent molecular work (Struwe et al. 1994) indicates a close relationship of the genera Labordia (Hawaiian endemic) and Geniostoma (of Pacific distribution). A separation of the two genera from Loganiaceae as Geniostomaceae (proposed by Struwe et al. 1994), however, is not accepted by the latest Angiosperm Phylogeny Group (2003) classification. The possibility of autochthonous polyploid evolution in the Geniostoma-Labordia relationship was discussed by Carr (1998) and Motley and Carr (1998). They gave $2 n=40$ for Geniostoma rupestre J. R. \& G. Forst., a possible ancestor of Labordia. Based on published data for Labordia $(2 n=80$ or $2 n=$ ca. 80 for $L$. birtella, L. waiolani [Carr 1978]; L. belleri, L. kaalae, L. tinifolia, L. fagraeoidea, L. bedyosmifolia, L. birtella, L. hosakana, L. waialealae, $L$. waiolani [Motley and Carr 1998]) and on unpublished counts by me (Labordia degeneri: $2 n>40<60$, L. belleri: $2 n=40-44$ [cited in Carr 1998]), the occurrence of at least two different ploidy levels in this Hawaiian endemic genus seemed apparent to Carr
(1998). In the light of the divergent data for L. belleri and the low number of counts available, Carr (1998:32) stated that "additional clarification and confirmation of the lower numbers determined by Kiehn (unpublished) ... would strengthen the case of autochthonous polyploidy in Labordia."

New data provided here give further evidence for the existence of different ploidy levels in the genus: besides tetraploidy and octoploidy (already revealed by earlier counts) hexaploidy could be present in $L$. degeneri, $L$. waialealae, and L. waiolani. These new results, however, also raise questions because there are now three species of Labordia (L. helleri, L. waialealae, L. waiolani) for which two different ploidy levels are reported. The result of $2 n>40<60$ for $L$. degeneri (Kiehn in Carr 1998) may indicate another instance of infraspecific polyploidy in Labordia. The range reported was due to the fact that the field fixation, Lorence DL6453, contained some cells with $2 n=\mathrm{ca} .40$ and others with $2 n=$ ca. 60 chromosomes, possibly because individuals at different ploidy levels were sampled in this fixation (this is the only fixation where the number of collected individuals is not known). In general, the data available for Labordia seem to reflect ongoing polyploidization at the species level in this genus. No meiotic irregularities were observed in L. waialealae; the range of $n=30-34$ is due to clumping of the chromosomes in the field fixation.

MYRSINACEAE: The count of $2 n=46$ for Myrsine sandwicensis is the first for the family in Hawai'i. The result is in accordance with most other data for the genus (Dawson 1995, Murray and DeLange 1999) and is not informative for phylogenetic considerations.

oleaceae: The result obtained for Nestegis sandwicensis is $2 n=44(-46)$. The reason for the given range is the presence of two smaller elements, most likely satellites but alternatively representing two small chromosomes. Skottsberg (1955) reported $2 n=44$ for N. sandwicensis. Counts made by Dawson (1995) revealed $2 n=46$ for four Nestegis species from New Zealand. More cytological investigations are needed to clarify the situation in this genus. 
ORCHIDACEAE: No chromosome counts for native Hawaiian orchids were available up to now. The reason for the range given here for Liparis hawaiensis from Maui $(2 n=26-30)$ is clumping of chromosomes in the field fixation. Variation of chromosome numbers ranging from $2 n=20$ to $2 n=76$ is documented for Liparis (Goldblatt and Johnson 2000), and B chromosomes are also reported in the genus (Vij and Sood 1986). Thus the data reported here have no obvious systematic implications.

pittosporaceae: Of the 11 Pittosporum species endemic to Hawai'i a previous count existed only for Pittosporum glabrum $(2 n=24$ [Carr 1978]). Outside Hawai'i, $x=n=12$ is the only reported number in the genus (Dawson 1995), and no polyploids have been reported (Fedorov 1974, Carr and McPherson 1986). The new result for P. gayanum $(2 n=24)$ matches the earlier results. However, $2 n=32-36$ obtained for two collections of Pittosporum, one from O'ahu and the other from Maui (neither identified to species), indicate the occurence of a new basic number in the genus. In this context, the report of $n=18$ for the genus Citriobatus by Gros (1965, cited in Fedorov 1974) deserves attention. The basic number for the family and the genus Pittosporum is probably $x=6$, and the two collections from $\mathrm{O}^{\prime}$ ahu and Maui are thus hexaploids. Further investigations, including meiotic divisions and pollen viability, are required to better understand the implications of the new reports.

Plantaginaceae: Two ploidy levels, $2 n=12$ and $2 n=24$, have been reported for the Hawaiian endemic Plantago princeps (Carr 1998). Three counts for this species are reported here, one for $P$. princeps s.str., and two for $P$. princeps var. anomala. All three reveal $2 n=24$ chromosomes. The second chromosomally known species from Hawai'i, $P$. pachyphylla, is also tetraploid with $2 n=24$ (Skottsberg 1955, Moore 1973). Thus, tetraploidy seems to be prevalent in the genus in Hawai'i. More counts are needed to verify the existence of diploidy in Hawaiian populations of Plantago.

POACEAE: Based on previous reports, Heteropogon contortus populations outside Hawai' $\mathrm{i}$ include diploids (mostly $n=10$ [e.g., Ahsan et al. 1994]) and tetraploids (either $n=18$ [e.g., Bir and Chauhan 1990] or $n=20$ [e.g., Gill et al. 1980, Sinha et al. 1990, Ahsan et al. 1994]). The same range of tetraploid numbers was obtained from analyses of field fixations of Heteropogon contortus from Hawai'i. The uncertainty reported here is due to several close associations of chromosomes not allowing a more exact count. It is not clear whether these associations reflect partial meiotic pairing (secondary associations) or are artifacts of the fixations. Such associations could explain the variation in chromosome numbers reported for this species in the literature.

The report of $2 n=42-44$ for Poa sandvicensis is the first report for a $P o a$ species native to Hawai'i. Based on available chromosome data, $x=7$ is the prevalent basic number in the genus Poa (Goldblatt and Johnson 2003), indicating that Poa sandvicensis is hexaploid. The fixation analyzed was a part of a young inflorescence of a single individual cultivated at the NTBG. Mitotic numbers were obtained from filament tissue that was presumably diploid (2n). Meiotic divisions of microsporocytes were present in all stages but were characterized by numerous univalents and multivalents and, therefore, did not allow a count. These irregularities in meiosis could be the effect of the hexaploid state of the plant.

Primulaceae: The native Hawaiian species of Lysimachia belong to two subgenera, subg. Palladia and subg. Lysimachiopsis. They are assumed to be the result of two separate colonization events (Wagner et al. 1999). This idea is supported by the cytological data: L. mauritiana, the only Hawaiian representative of subgenus Palladia, is diploid with $x=10 \quad(2 n=20 \quad$ [Carr 1978, 1998]). In contrast, both Hawaiian species of subg. Lysimachiopsis counted so far exhibit high chromosome numbers, most probably based on $x=9 ; 2 n=$ ca. 54 for L. billebrandii was reported by Skottsberg (1955), and the count given here for Lysimachia glutinosa $(2 n=72)$ matches an earlier report by Carr (1978). It would be desirable to sample additional Hawaiian species of subg. Lysimachiopsis to assess the extent of polyploidy. Chromosome size in 
Lysimachia glutinosa is $3-5 \mu \mathrm{m}$ in nearly fully contracted prometaphase, the same size range as given for other Lysimachia species (Ko et al. 1986).

RUBiaceae: Coprosma is represented in Hawai'i by 13 species, one of which, C. ernodeoides, has black fruits and is considered to represent an introduction independent from the remaining species, which have orange fruits (Wagner et al. 1999). The cytological situation in Coprosma has been discussed by Kiehn (1996). New counts for orange-fruited species $(2 n=44,40-44)$ are in accordance with all earlier reports for Hawaiian taxa, which exclusively were tetraploid (5 of 12 species counted). A new count for C. ernodeoides from Hawai'i Volcanoes National Park revealed $2 n=254-264$ chromosomes in each of six analyzed cells from two seedlings. This is the highest chromosome number reported in Rubiaceae so far. It also indicates the presence of two different ploidy levels in C. ernodeoides: an earlier count of this species (Kiehn 1996) based on material from East Maui and earlier data from the literature (Skottsberg $1955)$ showed $2 n=$ ca. 220. More cytological studies are needed to further elucidate this situation (e.g., whether the two ploidy levels distinguish populations of $C$. ernodeoides from East Maui and Hawai'i Island). Evidence for apomixis in the tetraploid C. waima from New Zealand (Heenan et al. 2002) suggests the possible occurrence of this mechanism in C. ernodeoides and could explain the regular fruit set in this species despite meiotic irregularities that are to be expected with such high chromosome numbers. Further work is needed to obtain additional chromosome data and to test for the possible occurrence of apomixis in C. ernodeoides.

For Hedyotis, three new results are reported here: a first count for H. schlechtendabliana subsp. remyi $(2 n=94-100)$, a new island report for $H$. centranthoides from O'ahu $(2 n=$ ca. 100$)$, and an additional count for $H$. terminalis from Kaua'i $(2 n=90-100)$. The new data fully support the earlier reports of very high chromosome numbers by Skottsberg (1955) and Kiehn (1996). The chromosomes of Hawaiian Hedyotis are dotlike and very small (not exceeding $0.5 \mu \mathrm{m}$ in mitotic metaphase), and it is very difficult to obtain clearly spread metaphase plates. Thus, the ranges of the counts reported here do not necessarily reflect a real range of chromosome number variation between individuals.

First counts for Hawaiian Psychotria (Kiehn and Lorence 1996) indicated the existence of two ploidy levels $(6 x, 8 x)$ in this genus in Hawai'i. The new count for P. mariniana corroborates the earlier result for this species (Kiehn and Lorence 1996). Unfortunately all other attempts to obtain results for Hawaiian Psychotria species have failed up to now due to "self-tanning" effects in the field fixations. Tannic acids present in tissues interfered with the field fixations in $P$. fauriei, $P$. greenwelliae, $P$. hathewayi, $P$. hawaiiensis, $P$. bexandra, and $P$. mauiensis, resulting in a prefixation of the chromosomes, which then clumped together, making counts virtually impossible (see Greilhuber 1987, Kiehn 1995 for discussions of this problem). Fixation of root tips of very young seedlings, which are nearly free of tannins, may provide a means to obtain accurate chromosome counts in these species.

RUTACEAE: Previous counts for Hawaiian species of Melicope established two ploidy levels: $2 n=36$ for M. elliptica (Carr 1978) of sect. Apocarpa, and $2 n=72$ for M. wawraeana of sect. Megacarpa (Guerra 1984, as Pelea wawraeana). Counts from outside Hawai'i are available for the two New Zealand species of Melicope: M. simplex and M. ternata are both reported to have $n=18$ and $2 n=36$ chromosomes (Guerra 1984, Dawson and Beuzenberg 2000). New results reported here for M. barbigera (sect. Apocarpa) and for an unidentified species from O'ahu (both $2 n=36$ ) match the earlier data. However, a third ploidy level is tentatively identified based on the observations made on four seedlings of an unidentified species from Kaua'i (Flynn 6630): one seedling clearly exhibited $2 n=18$, but the three others showed $2 n=36$. The implications of these results can only be evaluated when further counts become available.

SAPOTACEAE: The report by Skottsberg (1955) of $2 n=48$ for Pouteria sandwicensis could be interpreted as tetraploidy on a basic number of $x=12$ (Johnson 1991). Chromo- 
some data are also available for four Pouteria species from outside Hawai $i$, including $P$. aningeri, $P$. laevigata, and $P$. pariry $(2 n=28)$, and $P$. obovata $(2 n=26)$ (Johnson 1991). The counts for Pouteria sandwicensis presented here ( $n=12-13$ and $2 n=24-26)$ differ from the report of $2 n=48$ by Skottsberg (1955) for the same species. It appears that there may be both diploids and tetraploids in this species, with $x=12$ or 13 as the basic number. This result fits well with other cytological reports for tribe Chrysophylleae of the Sapotaceae (Johnson 1991). More cytological investigations on Pouteria sandwicensis are desirable to clarify this situation.

VIOLACEAE: The new count for Isodendrion pyrifolium $(2 n=16)$ is in accordance with the earlier results given by Carr (1985) for I. longifolium and I. subsessilifolium $(n=8)$. Three of the four species of this endemic Hawaiian genus are now known cytologically.

VISCACEAE: The data presented here for the Hawaiian Korthalsella cf. platycaula $(n=14-16,2 n=28-32)$ match the results for the three Korthalsella species from New Zealand $(2 n=28)$ investigated by Beuzenberg and Groves (1974). The range of the counts reported here was due to the large chromosomes (ca. 8-10 $\mu \mathrm{m}$ in mitotic metaphase) that were not spread well enough to allow more exact counts.

\section{Discussion of general aspects}

STATUS OF CHROMOSOME STUdies IN HAWAI'I: Before this study, there were no chromosome data available for 53 genera native to Hawaili (Carr 1998). In this paper the first data for three nonendemic genera and species are provided (see next sections). In addition, chromosome numbers were determined for one endemic species in each of two genera (Myrsine, Pteralyxia) not previously studied in Hawai'i. However, 48 genera with species native to Hawai'i still remain unknown cytologically.

Knowledge about the largest genus of Hawaiian angiosperms, Cyrtandra, is increased by one-third (chromosomes of 24 of 58 species and eight hybrids now counted). For the third largest genus in the Hawaiian Islands,
Melicope (Rutaceae), Carr (1978) stated that only one determination was available. With chromosome numbers for five taxa now known (ca. $10 \%$ of the Hawaiian species) and indications for at least two, if not three, different ploidy levels, the need for further investigation of this group is obvious.

CHROMOSOME NUMBERS OF NONENDEMIC HaWAIIAN TAXa: Carr (1998:6) mentioned that counts for 38 nonendemic Hawaiian species are available only for nonHawaiian material. In this paper the first reports of chromosome numbers based on Hawaiian material for three of these taxa representing three different genera are provided (Drosera anglica, Eleocharis obtusa, Heteropogon contortus). The results obtained for all three species are in accord with earlier counts on extra-Hawaiian material; no change in chromosome number has occurred in these taxa after their arrival in the Hawaiian Islands.

AUTOCHTHONOUS CHROMOSOME EVOLUTION IN HaWai'i: Carr (1998:26 and table 1.1) noted reports indicating interspecific or interpopulational variation of the chromosome number in at least 38 genera of Hawaiian angiosperms. Some of the reports of such variation (e.g., in the Campanulaceae, and in the Asteraceae genera Argyroxipbium, Bidens, Tetramolopium, and Wilkesia) were considered by Carr (1998) "to be almost certainly the result of faulty cytological determinations," a statement that, for the Campanulaceae, is supported by the results reported here. The additional new data for Alyxia and Silene give no indication for chromosomal variation in these two genera in the Hawaiian Islands.

There are some Hawaiian plant groups mentioned by Carr (1998) as potentially exhibiting autochthonous chromosomal evolution. In this context Carr (1998:26) stated that "it would be especially gratifying to have more data for Acacia, Coprosma, Gouania, Hedyotis, Hibiscus, Lysimachia, Phyllostegia, Plantago, Psychotria, Ranunculus, and Rumex." In this paper new data for four of those 11 genera are included. New evidence for variation (different ploidy levels) is provided for the genera Coprosma, Hedyotis, and Psychotria, but the new data increase the doubts about the existence of two ploidy levels in the genus 
Plantago in Hawaici. The new counts provided here give further evidence for chromosomal variation in four of the 16 genera mentioned by Carr (1998) as examples of real variation: Coprosma, Labordia, Lysimachia, and Psychotria. More than $80 \%$ of the cytologically investigated Hawaiian taxa are polyploids (Carr 1998). Chromosome numbers of Hawaiian species are often among the highest records for the corresponding genera (Kiehn and Lorence 1996, Carr 1998). Most polyploid species are considered to be paleopolyploids, with polyploidy evolved before dispersal of the ancestors to the Hawaiian archipelago (Carr 1998). Cases of potentially autochthonous polyploid evolution on Hawai'i were listed and discussed by Carr (1998). Based on the findings reported here, there are additions to this list: Coprosma ernodeoides (Rubiaceae), Melicope (Rutaceae), and Vaccinium (Ericaceae). Further investigations are required to evaluate the observed variation in Pittosporum.

CHROMOSOME STASIS IN AUTOCHTHONOUS HAWAIIAN PLANT GROUPS: In two groups the existence of chromosome stasis in Hawai' $i$ is further supported. In the genus Cyrtandra, the new karyological data (especially for the interspecific hybrids) show that the enormous morphological variation of the 58 endemic species of this genus in Hawai $i$, which most probably are the result of a single colonization event (Samuel et al. 1997, Kiehn 2001), is not paralleled by cytological variation. The same holds true for the very large number of endemic species of Campanulaceae, composing more than $10 \%$ of the native flowering plants of Hawai'i.

CHROMOSOME DATA AND COLONIZATION events: Besides Cyrtandra, there are indications of single colonization events for the Hawaiian species of the family Ericaceae (Vander Kloet 1996) and of the genus Labordia. Two colonization events are suggested for Coprosma, Psychotria, Lysimachia, and Melicope (Wagner et al. 1999) and a single to very few colonization events for all ca. 110 species of Hawaiian Campanulaceae (Givnish et al. 1995). The available chromosome data support these hypotheses for the Campanulaceae and for Cyrtandra, Coprosma, Lysimachia, and
Melicope. They are also not contradicting the hypothesis of reticulate speciation in Ericaceae (Vander Kloet 1996). The cytological picture is not yet clear for Psychotria.

\section{CONCLUSIONS}

The new data support the conclusions by Kiehn and Lorence (1996) and Carr (1998) that the degree of chromosomal variation in autochthonous Hawaiian plant groups in most cases reflects the variation of their continental ancestors-in relationships variable outside Hawai'i (such as Psychotria) the probability of variation being found in Hawai'i is also higher. Insular variation might be the result of different colonization events by taxa with different chromosome numbers (e.g., in Lysimachia and Coprosma). However, autochthonous insular chromosome evolution, considered by Stuessy and Crawford (1998) to be rare, seems to be found preferentially in groups with continental ancestors already possessing cytological variability (e.g., Hedyotis [see also Kiehn and Lorence 1996, Carr 1998]).

The role of time in autochthonous chromosomal evolution events cannot be evaluated in most cases because of the lack of data related to time of colonization of the lineage in question. However, in at least two groups exhibiting chromosome stasis in Hawai'i (Campanulaceae and Cyrtandra) there are indications for recent speciation in $\mathrm{Ha}$ wai'i (Lammers 1988; H. K., unpubl. data). The newly observed cases of chromosomal variation in groups with little or no previous data (Coprosma ernodeoides, Melicope, Vaccinium, and possibly Pittosporum) clearly indicate the need for further chromosomal studies of the Hawaiian flora.

\section{ACKNOWLEDGMENTS}

I thank all institutions in Hawai' $i$ that facilitated the work, especially the National Tropical Botanical Garden, Lāwa'i, Kaua'i; the Bishop Museum, Honolulu; and the Maui Land and Pineapple Company, Maui. Collecting permits obtained from the Kōke'e State Park, Kaua'i; the National Park Service 
(Volcanoes National Park, Big Island); The Nature Conservancy (Moloka $\mathrm{i}$ ); and the U.S. Army (O'ahu) are gratefully acknowledged. Thanks are due to friends and colleagues who helped in the field and with identifications of collections, especially L. (Cuddihy) Pratt, T. Flynn, R. Hobdy, C. Imada, T. Lammers, D. H. Lorence, J. Obata, H. Oppenheimer, S. Perlman, C. Puttock, J. Smith, T. Takahama, W. L. Wagner, and K. Wood. Monika Kiehn and N. Lux (Vienna) were most helpful in organizing and carrying out the excursions and the work in the field. D. H. Lorence (NTBG, Kaua'i) and M. Moeller (Royal Botanic Gardens, Edinburgh) are thanked for suggestions and critical comments on the manuscript.

\section{Literature Cited}

Ahsan, S. M. N., A. A. Vahidy, and S. I. Ali. 1994. Chromosome numbers and incidence of polyploidy in Panicoideae (Poaceae) from Pakistan. Ann. Mo. Bot. Gard. 81:775-783.

Angiosperm Phylogeny Group. 2003. An update of the Angiosperm Phylogeny Group classification for the orders and families of flowering plants: APG II. Bot. J. Linn. Soc. 141:399-436.

Beuzenberg, E. J., and B. E. Groves. 1974. Contributions to a chromosome atlas of the New Zealand flora. 16. Miscellaneous families. N. Z. J. Bot. 12:211-217.

Bir, S. S., and H. S. Chauhan. 1990. SOCGI plant chromosome number reports X. J. Cytol. Genet. 25:322-323.

Borgmann, E. 1964. Anteil der Polyploiden in der Flora des Bismarckgebirges von Ostneuguinea. Z. Bot. 52:118-173.

Carr, G. D. 1978. Chromosome numbers of Hawaiian flowering plants and the significance of cytology in selected taxa. Am. J. Bot. 65:236-242.

- 1985. Additional chromosome numbers of Hawaiian flowering plants. Pac. Sci. 39:302-306.

1995. A fully fertile intergeneric hybrid derivative from Argyroxiphium sandwicense ssp. macrocephalum x Dubautia menziesii (Asteraceae) and its relevance to plant evolution in the Hawaiian Islands. Am. J. Bot. 82:1574-1581.

- 1998. Chromosome evolution and speciation in Hawaiian flowering plants. Pages 5-47 in T. F. Stuessy and M. Ono, eds. Evolution and speciation of island species. Cambridge University Press, Cambridge.

Carr, G. D., and G. McPherson. 1986. Chromosome numbers of New Caledonian plants. Ann. Mo. Bot. Gard. 73:486-489.

Dawson, M. I. 1995. Contributions to a chromosome atlas of the New Zealand flora. 34. Miscellaneous species. N. Z. J. Bot. 33:477-487.

Dawson, M. I., and E. J. Beuzenberg. 2000. Contributions to a chromosome atlas of the New Zealand flora. 36. Miscellaneous families. N. Z. J. Bot. 38:1-23.

Fedorov, A. A., ed. 1974. Chromosome numbers of flowering plants. Academy of Sciences of the USSR, Leningrad.

Gervais, C., and J. Cayouette. 1985. Liste annotée de nombres chromosomiques de la flore vasculaire du nord-est de l'Amerique IV. Nat. Can. (Que.) 112:319-331.

Gibby, M., S. Hinnah, E. M. Marais, and F. Albers. 1996. Cytological variation and evolution within Pelargonium section Hoarea (Geraniaceae). Plant Syst. Evol. 203:111-142.

Gill, B. S., S. S. Bir, V. K. Singhal, and Y. S. Bedi. 1980. Cytological studies on some grasses from Pachmarhi forest (central India). J. Cytol. Genet. 15:51-57.

Givnish, T. J., K. J. Sytsma, J. F. Smith, and W. J. Hahn. 1995. Molecular evolution, adaptive radiation, and geographic speciation in Cyanea (Campanulaceae, Lobelioideae). Pages 288-337 in W. L. Wagner and V. A. Funk, eds. Hawaiian biogeography: Evolution on a hot spot archipelago. Smithsonian Institution Press, Washington, D.C.

Goldblatt, P., and D. E. Johnson, eds. 1990. Index to plant chromosome numbers 1986-1987. Monogr. Syst. Bot. 30.

- 2000. Index to plant chromosome numbers 1996-1997. Monogr. Syst. Bot. 81.

- 2003. Index to plant chromosome 
numbers 1998-2000. Monogr. Syst. Bot. 94.

Greilhuber, J. 1987. "Self-tanning"-a new and important source of stoichiometric error in cytophotometric determination of nuclear DNA content in plants. Plant Syst. Evol. 158:87-96.

Gros, J.-P. 1965. Contribution à l'étude cytotaxonomique des Pittosporacées. Mem. Mus. Natl. Hist. Nat. Ser. B Bot. 16:6190.

Guerra, M. dos S. 1984. New chromosome numbers in Rutaceae. Plant Syst. Evol. 146:13-30.

Heenan, P. B., M. I. Dawson, and R. A. Bicknell. 2002. Evidence for apomictic seed formation in Coprosma waima (Rubiaceae). N. Z. J. Bot. 40:347-355.

Holmgren, P. K., N. H. Holmgren, and L. C. Barnett. 1990. Index herbariorum. Part 1: The herbaria of the world. 8th ed. New York Botanical Garden, Bronx, New York.

Johnson, M. 1991. Cytology. Pages 15-22 in T. D. Pennington, ed. The genera of Sapotaceae. Royal Botanic Gardens, Kew, U.K.

Kiehn, M. 1995. Chromosome survey of the Rubiaceae. Ann. Mo. Bot. Gard. 82:398408.

- 1996. Chromosomes of Rubiaceae occurring in Malesia, the Philippines, New Guinea, and the Pacific. Opera Bot. Belg. $7: 249-260$.

- 2001. South Pacifc and Hawaiian Cyrtandra: Molecular and micromorphological studies. Malay. Nat. J. 55:21-27.

Kiehn, M., and D. H. Lorence. 1996. Chromosome counts on angiosperms cultivated at the National Tropical Botanical Garden, Kaua'i, Hawai'i. Pac. Sci. 50:317-323.

Kiehn, M., and A. Weber. 1998. Chromosome numbers of Malayan and other paleotropical Gesneriaceae. II. Tribes Trichosporeae, Cyrtandreae and Epithemateae. Beitr. Biol. Pflanz. 70 (1997): 445-470.

Ko, S. C., I. T. Im, and Y. S. Kim. 1986. A cytotaxonomic study on the genus Lysimachia in Korea. Korean J. Plant Taxon. 16:187-197.

Kondo, K., and P. S. Lavarack. 1984. A cytotaxonomic study of some Australian spe- cies of Drosera L. (Droseraceae). Bot. J. Linn. Soc. 88:317-333.

Kondo, K., and M. Segawa. 1988. A cytotaxonomic study in artificial hybrids between Drosera anglica Huds. and its certain closely related species in series Drosera, section Drosera, subgenus Drosera, Drosera. Kromosomo (Tokyo) 51-52:1697-1709.

Lammers, T. G. 1988. Chromosome numbers and their systematic implications in Hawaiian Lobelioideae (Campanulaceae). Am. J. Bot. 75:1130-1134.

Luegmayr, E. 1993. Pollen of Hawaiian Cyrtandra (Gesneriaceae) including notes on Southeast Asian taxa. Blumea 38:25-38.

Middleton, D. J. 2000. Revision of Alyxia (Apocynaceae). Part 1: Asia and Malesia. Blumea 45:1-146.

Moore, R. J., ed. 1973. Index to plant chromosome numbers 1967-1971. Regnum Veg. 90.

Motley, T. J., and G. D. Carr. 1998. Artificial hybridization in the Hawaiian endemic genus Labordia (Loganiaceae). Am. J. Bot. 85:654-660.

Murín, A., and J. Májovský. 1987. Karyological study of the Slovak flora XIX. Acta Fac. Rerum Nat. Univ. Comenianae Bot. 34:320.

Murray, B. G., and P. J. DeLange. 1999. Contributions to a chromosome atlas of the New Zealand flora. 35. Miscellaneous families. N. Z. J. Bot. 37:511-521.

Samuel, R., W. Pinsker, and M. Kiehn. 1997. Phylogeny of some species of Cyrtandra (Gesneriaceae) inferred from the atp/rbcL cpDNA intergene region. Bot. Acta 110:503-510.

Sheikh, S. A., and K. Kondo. 1995. Differential staining with orcein, Giemsa, CMA, and DAPI for comparative chromosome study of 12 species of Australian Drosera (Droseraceae). Am. J. Bot. 82:1278-1286.

Sinha, R. R. P., A. K. Bhardwaj, and R. K. Singh. 1990. SOCGI plant chromosome number reports IX. J. Cytol. Genet. 25: 140-143.

Skottsberg, C. 1955. Chromosome numbers in Hawaiian flowering plants. Ark. Bot. 59:63-70.

Storey, W. B. 1966. Chromosome numbers 
in Cyrtandra. Pages 31-33 in H. St. John. Monograph of Cyrtandra (Gesneriaceae) on Oahu, Hawaiian Islands. Bernice P. Bishop Mus. Bull. 229.

Struwe, L., V. A. Albert, and B. Bremer. 1994 [1995]. Cladistics and family level classification of the Gentianales. Cladistics 10:175-206.

Stuessy, T. F., and D. J. Crawford. 1998. Chromosomal stasis during speciation in angiosperms of oceanic islands. Pages 307-324 in T. F. Stuessy and M. Ono, eds. Evolution and speciation of island species. Cambridge University Press, Cambridge.

Vander Kloet, S. P. 1996. Taxonomy of Vaccinium Section Macropelma (Ericaceae). Syst. Bot. 21:355-364.

Van der Laan, F. M., and J. C. Arends. 1985.
Cytotaxonomy of Apocynaceae. Genetica (The Hague) 68:3-35.

Vij, S. P., and R. Sood. 1986. Cytology in relation to morphology in Spiranthes lancea (Sw.) Backer. Pages 147-161 in S. P. Vij, ed. Biology, conservation, and culture of orchids. Affiliated East-West Press, New Delhi. (Cited in Goldblatt and Johnson 1990.)

Wagner, W. L., D. R. Herbst, and S. H. Sohmer. 1999. Manual of the flowering plants of Hawai'i. Rev. ed. Bishop Mus. Spec. Publ. 97. University of Hawai' $i$ Press/Bishop Museum Press, Honolulu.

Wen, J., G. M. Plunkett, A. D. Mitchell, and S. J. Wagstaff. 2001. The evolution of Araliaceae: A phylogenetic analysis based on ITS sequences of nuclear ribosomal DNA. Syst. Bot. 26:144-167. 
